\title{
the lady and the mill girl: changes in the status of women in the age of jackson
}

\author{
gerda lerner
}

The period 1800-1840 is one in which decisive changes occurred in the status of American women. It has remained surprisingly unexplored. With the exception of a recent, unpublished dissertation by Keith Melder and the distinctive work of Elisabeth Dexter, there is a dearth of descriptive material and an almost total absence of interpretation. ${ }^{1}$ Yet the period offers essential clues to an understanding of later institutional developments, particularly the shape and nature of the women's rights movement. This analysis will consider the economic, political and social status of women and examine the changes in each area. It will also attempt an interpretation of the ideological shifts which occurred in American society concerning the "proper" role for women.

Periodization always offers difficulties. It seemed useful here, for purposes of comparison, to group women's status before 1800 roughly under the "colonial" heading and ignore the transitional and possibly atypical shifts which occurred during the American Revolution and the early period of nationhood. Also, regional differences were largely ignored. The South was left out of consideration entirely because its industrial development occurred later.

The status of colonial women has been well studied and described and can briefly be summarized for comparison with the later period. Throughout the colonial period there was a marked shortage of women, which varied with the regions and always was greatest in the frontier areas. ${ }^{2}$ This (from the point of view of women) favorable sex ratio enhanced their status and position. The Puritan world view regarded idleness as sin; life in an underdeveloped country made it absolutely necessary that each member of the community perform an economic function. Thus work for women, married or single, was not only approved, it was regarded as a civic duty. Puritan town councils expected single girls, 
widows and unattached women to be self-supporting and for a long time provided needy spinsters with parcels of land. There was no social sanction against married women working; on the contrary, wives were expected to help their husbands in their trade and won social approval for doing extra work in or out of the home. Needy children, girls as well as boys, were indentured or apprenticed and were expected to work for their keep.

The vast majority of women worked within their homes, where their labor produced most articles needed for the family. The entire colonial production of cloth and clothing and partially that of shoes was in the hands of women. In addition to these occupations, women were found in many different kinds of employment. They were butchers, silversmiths, gunsmiths, upholsterers. They ran mills, plantations, tan yards, shipyards and every kind of shop, tavern and boarding house. They were gate keepers, jail keepers, sextons, journalists, printers, "doctoresses," apothecaries, midwives, nurses and teachers. Women acquired their skills the same way as did the men, through apprenticeship training, frequently within their own families. ${ }^{3}$

Absence of a dowry, ease of marriage and remarriage and a more lenient attitude of the law with regard to woman's property rights were manifestations of the improved position of wives in the colonies. Under British common law, marriage destroyed a woman's contractual capacity; she could not sign a contract even with the consent of her husband. But colonial authorities were more lenient toward the wife's property rights by protecting her dower rights in her husband's property, granting her personal clothing and upholding pre-nuptial contracts between husband and wife. In the absence of the husband, colonial courts granted women "femme sole" rights, which enabled them to conduct their husband's business, sign contracts and sue. The relative social freedom of women and the esteem in which they were held was commented upon by most early foreign travelers in America. ${ }^{4}$

But economic, legal and social status tell only part of the story. Colonial society as a whole was hierarchical, and rank and standing in society depended on the position of the men. Women did not play a determining role in the ranking pattern; they took their position in society through the men of their own family or the men they married. In other words, they participated in the hierarchy only as daughters and wives, not as individuals. Similarly, their occupations were, by and large, merely auxiliary, designed to contribute to family income, enhance their husbands' business or continue it in case of widowhood. The self-supporting spinsters were certainly the exception. The underlying assumption of colonial society was that women ought to occupy an inferior and subordinate position. The settlers had brought this assumption with them from Europe; it was reflected in their legal concepts, their willingness to exclude women from political life, their discriminatory 
educational practices. What is remarkable is the extent to which this felt inferiority of women was constantly challenged and modified under the impact of environment, frontier conditions and a favorable sex ratio.

By 1840 all of American society had changed. The Revolution had substituted an egalitarian ideology for the hierarchical concepts of colonial life. Privilege based on ability rather than inherited status, upward mobility for all groups of society and unlimited opportunities for individual self-fulfillment had become ideological goals, if not always realities. For men, that is; women were, by tacit consensus, excluded from the new democracy. Indeed their actual situation had in many respects deteriorated. While, as wives, they had benefitted from increasing wealth, urbanization and industrialization, their role as economic producers and as political members of society differed sharply from that of men. Women's work outside of the home no longer met with social approval; on the contrary, with two notable exceptions, it was condemned. Many business and professional occupations formerly open to women were now closed, many others restricted as to training and advancement. The entry of large numbers of women into low status, low pay and low skill industrial work had fixed such work by definition as "woman's work." Women's political status, while legally unchanged, had deteriorated relative to the advances made by men. At the same time the genteel lady of fashion had bec`me a model of American femininity and the definition of "woman's pre per sphere" seemed narrower and more confined than ever.

Within the scope of this article only a few of these changes can be more fully explained. The professionalization of medicine and its impact on women may serve as a typical example of what occurred in all the professions.

In colonial America there were no medical schools, no medical journals, few hospitals and few laws pertaining to the practice of the healing arts. Clergymen and governors, barbers, quacks, apprentices and women practiced medicine. Most practitioners acquired their credentials by reading Paracelsus and Galen and serving an apprenticeship with an established practitioner. Among the semi-trained "physics," surgeons and healers the occasional "doctoress" was fully accepted and frequently well rewarded. County records of all the colonies contain references to the work of the female physicians. There was even a female Army surgeon, a Mrs. Allyn, who served during King Philip's war. Plantation records mention by name several slave women who were granted special privileges because of their useful service as midwives and "doctoresses."

The period of the professionalization of American medicine dates from 1765, when Dr. William Shippen began his lectures on midwifery in Philadelphia. The founding of medical faculties in several colleges, the standardization of training requirements and the proliferation of medical societies intensified during the last quarter of the eighteenth 
century. The American Revolution dramatized the need for trained medical personnel, afforded first hand battlefield experience to a number of surgeons and brought increasing numbers of semi-trained practitioners in contact with the handful of European-trained surgeons working in the military hospitals. This was an experience from which women were excluded. The resulting interest in improved medical training, the gradual appearance of graduates of medical colleges and the efforts of medical societies led to licensing legislation. In 1801 Maryland required all medical practitioners to be licensed; in 1806 New York enacted a similar law, providing for an examination before a commission. By the late 1820's all states except three had set up licensing requirements. Since most of these laws stipulated attendance at a medical college as one of the prerequisites for licensing, women were automatically excluded. ${ }^{6}$ By the 1830's the few established female practitioners who might have continud their practice in the old ways had probably died out. Whatever vested interest they had had was too weak to assert itself against the new profession.

This process of pre-emption of knowledge, institutionalization of the profession and legitimation of its claims by law and public acceptance is standard for the professionalization of the sciences, as George Daniels has pointed out. ${ }^{7}$ It inevitably results in the elimination of fringe elements from the profession. It is interesting to note that women had been pushed out of the medical profession in sixteenth-century Europe by a similar process. ${ }^{8}$ Once the public had come to accept licensing and college training as guarantees of up-to-date practice the outsider, no matter how well qualified by years of experience, stood no chance in the competition. Women were the casualties of medical professionalization.

In the field of midwifery the results were similar, but the process was more complicated. Women had held a virtual monopoly in the profession in colonial America. In 1646 a man was prosecuted in Maine for practicing as a midwife. ${ }^{9}$ There are many records of well trained midwives with diplomas from European institutions working in the colonies. In most of the colonies midwives were licensed, registered and required to pass an examination before a board. When Dr. Shippen announced his pioneering lectures on midwifery, he did it to "combat the widespread popular prejudice against the man-midwife" and because he considered most midwives ignorant and improperly trained. ${ }^{10}$

Yet he invited "those women who love virtue enough, to own their Ignorance, and apply for instruction" to attend his lectures, offering as an inducement the assurance that female pupils would be taught privately. It is not known if any midwives availed themselves of the opportunity. ${ }^{11}$

Technological advances, as well as scientific, worked against the interests of female midwives. In sixteenth-century Europe the invention 
and use of the obstetrical forceps had for three generations been the wellkept secret of the Chamberlen family and had greatly enhanced their medical practice. Hugh Chamberlen was forced by circumstances to sell the secret to the Medical College in Amsterdam, which in turn transmitted the precious knowledge to licensed physicians only. By the time the use of the instrument became widespread it had become associated with male physicians and midwives. Similarly in America, introduction of the obstetrical forceps was associated with the practice of male midwives and served to their advantage. By the end of the eighteenth century a number of male physicians advertised their practice of midwifery. Shortly thereafter female midwives also resorted to advertising, probably in an effort to met the competition. By the early nineteenth century male physicians had virtually monopolized the practice of midwifery on the Eastern seaboard. True to the generally delayed economic development in the Western frontier regions, female midwives continued to work on the frontier until a much later period. It is interesting to note that the concepts of "propriety" shifted with the prevalent practice. In seventeenth-century Maine the attempt of a man to act as a midwife was considered outrageous and illegal; in mid-nineteenth-century America the suggestion that women should train as midwives and physicians was considered equally outrageous and improper. ${ }^{12}$

Professionalization, similar to that in medicine with the elimination of women from the upgraded profession, occurred in the field of law. Before 1750, when law suits were commonly brought to the courts by the plaintiffs themselves or by deputies without specialized legal training, women as well as men could and did act as "attorneys-in-fact." When the law became a paid profession and trained lawyers took over litigation, women disappeared from the court scene for over a century. ${ }^{13}$

A similar process of shrinking opportunities for women developed in business and in the retail trades. There were fewer female storekeepers and business women in the 1830's than there had been in colonial days. There was also a noticeable shift in the kind of merchandise handled by them. Where previously women could be found running almost every kind of retail shop, after 1830 they were mostly found in businesses which served women only. ${ }^{14}$

The only fields in which professionalization did not result in the elimination of women from the upgraded profession were nursing and teaching. Both were characterized by a severe shortage of labor. Nursing lies outside the field of this inquiry since it did not become an organized profession until after the Civil War. Before then it was regarded peculiarly as a woman's occupation, although some of the hospitals and the Army during wars employed male nurses. These bore the stigma of low skill, low status and low pay. Generally, nursing was regarded as simply an extension of the unpaid services performed by the housewife-a characteristic attitude that haunts the profession to this day. 
Education seems, at first glance, to offer an entirely opposite pattern from that of the other professions. In colonial days women had taught "Dame schools" and grade schools during summer sessions. Gradually, as educational opportunities for girls expanded, they advanced just a step ahead of their students. Professionalization of teaching occurred between 1820-1860, a period marked by a sharp increase in the number of women teachers. The spread of female seminaries, academies and normal schools provided new opportunities for the training and employment of female teachers.

This trend which runs counter to that found in the other professions can be accounted for by the fact that women filled a desperate need created by the challenge of the common schools, the ever-increasing size of the student body and the westward growth of the nation. America was committed to educating its children in public schools, but it was insistent on doing so as cheaply as possible. Women were available in great numbers and they were willing to work cheaply. The result was another ideological adaptation: in the very period when the gospel of the home as woman's only proper sphere was preached most loudly, it was discovered that women were the natural teachers of youth, could do the job better than men and were to be preferred for such employment. This was always provided, of course, that they would work at the proper wage differential- $30-50 \%$ of the wages paid male teachers was considered appropriate. The result was that in 1888 in the country as a whole $63 \%$ of all teachers were women, while the figure for the cities only was $90.04 \% \cdot{ }^{15}$

It appeared in the teaching field, as it would in industry, that role expectations were adaptable provided the inferior status group filled a social need. The inconsistent and peculiar patterns of employment of black labor in the present-day market bear out the validity of this generalization.

There was another field in which the labor of women was appreciated and which they were urged to enter-industry. From Alexander Hamilton to Matthew Carey and Tench Coxe, advocates of industrialization sang the praises of the working girl and advanced arguments in favor of her employment. The social benefits of female labor particularly stressed were those bestowed upon her family, who now no longer had to support her. Working girls were "thus happily preserved from idleness and its attendant vices and crimes" and the whole community benefitted from their increased purchasing power. ${ }^{16}$

American industrialization, which occurred in an underdeveloped economy with a shortage of labor, depended on the labor of women and children. Men were occupied with agricultural work and were not available or willing to enter the factories. This accounts for the special features of the early development of the New England textile industry: the relatively high wages, the respectability of the job and relatively 
high status of the mill girls, the patriarchal character of the model factory towns and the temporary mobility of women workers from farm to factory and back again to farm. All this was characteristic only of a limited area and of a period of about two decades. By the late 1830's the romance had worn off; immigration had supplied a strongly competitive, permanent work force willing to work for subsistence wages; early efforts at trade union organization had been shattered and mechanization had turned semiskilled factory labor into unskilled labor. The process led to the replacement of the New England-born farm girls by immigrants in the mills and was accompanied by a loss of status and respectability for female workers.

The lack of organized social services during periods of depression drove ever greater numbers of women into the labor market. At first, inside the factories distinctions between men's and women's jobs were blurred. Men and women were assigned to machinery on the basis of local need. But as more women entered industry the limited number of occupations open to them tended to increase competition among them, thus lowering pay standards. Generally, women regarded their work as temporary and hesitated to invest in apprenticeship training, because they expected to marry and raise families. Thus they remained untrained, casual labor and were soon, by custom, relegated to the lowest paid, least skilled jobs. Long hours, overwork and poor working conditions would characterize women's work in industry for almost a century. ${ }^{17}$

Another result of industrialization was in increasing differences in life styles between women of different classes. When female occupations, such as carding, spinning and weaving, were transferred from home to factory, the poorer women followed their traditional work and became industrial workers. The women of the middle and upper classes could use their newly gained time for leisure pursuits: they became ladies. And a small but significant group among them chose to prepare themselves for professional careers by advanced education. This group would prove to be the most vocal and troublesome in the near future.

As class distinctions sharpened, social attitudes toward women became polarized. The image of "the lady" was elevated to the accepted ideal of femininity toward which all women would strive. In this formulation of values lower class women were simply ignored. The actual lady was, of course, nothing new on the American scene; she had been present ever since colonial days. What was new in the 1830's was the cult of the lady, her elevation to a status symbol. The advancing prosperity of the early nineteenth century made it possible for middle class women to aspire to the status formerly reserved for upper class women. The "cult of true womanhood" of the 1830's became a vehicle for such aspirations. Mass circulation newspapers and magazines made it possible to teach every woman how to elevate the status of her family by setting "proper" standards of behavior, dress and literary tastes. Godey's Lady's Book and 
innumerable gift books and tracts of the period all preach the same gospel of "true womanhood"-piety, purity, domesticity. ${ }^{18}$ Those unable to reach the goal of becoming ladies were to be satisfied with the lesser goal-acceptance of their "proper place" in the home.

It is no accident that the slogan "woman's place is in the home" took on a certain aggressiveness and shrillness precisely at the time when increasing numbers of poorer women left their homes to become factory workers. Working women were not a fit subject for the concern of publishers and mass media writers. Idleness, once a disgrace in the eyes of society, had become a status symbol. Thorstein Veblen, one of the earliest and sharpest commentators on the subject, observed that it had become almost the sole social function of the lady "to put in evidence her economic unit's ability to pay." She was "a means of conspicuously unproductive expenditure," devoted to displaying her husband's wealth. ${ }^{19}$ Just as the cult of white womanhood in the South served to preserve a labor and social system based on race distinctions, so did the cult of the lady in an egalitarian society serve as a means of preserving class distinctions. Where class distinctions were not so great, as on the frontier, the position of women was closer to what it had been in colonial days; their economic contribution was more highly valued, their opportunities were less restricted and their positive participation in community life was taken for granted.

In the urbanized and industrialized Northeast the life experience of middle class women was different in almost every respect from that of the lower class women. But there was one thing the society lady and the mill girl had in common-they were equally disfranchised and isolated from the vital centers of power. Yet the political status of women had not actually deteriorated. With very few exceptions women had neither voted nor stood for office during the colonial period. Yet the spread of the franchise to ever wider groups of white males during the Jacksonian age, the removal of property restrictions, the increasing numbers of immigrants who acquired access to the franchise, made the gap between these new enfranchised voters and the disfranchised women more obvious. Quite naturally, educated and propertied women felt this deprivation more keenly. Their own career expectations had been encouraged by widening educational opportunities; their consciousness of their own abilities and of their potential for power had been enhanced by their activities in the reform movements of the 1830's; the general spirit of upward mobility and venturesome entrepreneurship that pervaded the Jacksonian era was infectious. But in the late 1840's a sense of acute frustration enveloped these educated and highly spirited women. Their rising expectations had met with frustration, their hopes had been shattered; they were bitterly conscious of a relative lowering of status and a loss of position. This sense of frustration led them to action; it was one of the main factors in the rise of the woman's rights movement. ${ }^{20}$ 
The women, who in 1848 declared boldly and with considerable exaggeration that "the history of mankind is a history of repeated injuries and usurpations on the part of man toward woman, having in direct object the establishment of an absolute tyranny over her," did not speak for the truly exploited and abused working woman. ${ }^{21}$ As a matter of fact, they were largely ignorant of her condition and, with the notable exception of Susan B. Anthony, indifferent to her fate. But they judged from the realities of their own life experience. Like most revolutionaries, they were not the most downtrodden but rather the most status-deprived group. Their frustrations and traditional isolation from political power funneled their discontent into fairly utopian declarations and immature organizational means. They would learn better in the long, hard decades of practical struggle. Yet it is their initial emphasis on the legal and political "disabilities" of women which has provided the framework for most of the historical work on women. For almost a hundred years sympathetic historians have told the story of women in America from the feminist viewpoint. Their tendency has been to reason from the position of middle class women to a generalization concerning all American women. This distortion has obscured the actual and continuous contributions of women to American life. ${ }^{22}$ To avoid such a distortion, any valid generalization concerning American women after the 1830 's should reflect a recognition of class stratification.

For lower class women the changes brought by industrialization were actually advantageous, offering income and advancement opportunities, however limited, and a chance for participation in the ranks of organized labor. They, by and large, tended to join men in their struggle for economic advancement and became increasingly concerned with economic gains and protective labor legislation. Middle and upperclass women, on the other hand, reacted to actual and fancied status deprivation by increasing militancy and the formation of organizations for women's rights, by which they meant especially legal and property rights.

The four decades preceding the Seneca Falls Convention were decisive in the history of American women. They brought an actual deterioration in the economic opportunities open to women, a relative deterioration in their political status and a rising level of expectation and subsequent frustration in a privileged elite group of educated women. The ideology still pervasive in our present-day society regarding woman's "proper" role was formed in those decades. Later, under the impact of feminist attacks this ideology would grow defensive and attempt to bolster its claims by appeals to universality and pretentions to a history dating back to antiquity or, at least, to The Mayflower. Women, we are told, have always played a restricted and subordinate role in American life. In fact, however, it was in mid-nineteenth-century America that the ideology of "woman's place is in the home" changed from being an accurate description of existing reality into a myth. It 
became the "feminine mystique" - a longing for a lost, archaic world of agrarian family self-sufficiency, updated by woman's consumer function and the misunderstood dicta of Freudian psychology.

The decades 1800-1840 also provide the clues to an understanding of the institutional shape of the later women's organizations. These would be led by middle class women whose self-image, lif'e experience and ideology had largely been fashioned and influenced by these early, transitional years. The concerns of middle class women-property rights, the franchise and moral uplift-would dominate the women's rights movement. But side by side with it, and at times cooperating with it, would grow a number of organizations serving the needs of working women.

American women were the largest disfranchised group in the nation's history, and they retained this position longer than any other group. Although they found ways of making their influence felt continuously, not only as individuals but as organized groups, power eluded them. The mill girl and the lady, both born in the age of Jackson, would not gain access to power until they learned to cooperate, each for her own separate interests. It would take almost six decades before they would find common ground. The issue around which they finally would unite and push their movement to victory was the "impractical and utopian" demand raised at Seneca Falls - the means to power in American societyfemale suffrage.

Sarah Lawrence College

\section{footnotes}

Research for this article was facilitated by a research grant provided by Long Island University, Brooklyn, N.Y., which is gratefuily acknowledged.

The generalizations in this article are based on extensive research in primary sources, including letters and manuscripts of the following women: Elizabeth Cady Stanton, Susan $B$. Anthony, Abby Kelley, Lucretia Mott, Lucy Stone, Sarah and Angelina Grimke, Maria Weston Chapman, Lydia Maria Child and Betsey Cowles. Among the organizational records consulted were those of the Boston Female Anti-Slavery Society, the Philadelphia Female Anti-Slavery Society, Anti-Slavery Conventions of American Women, all the Woman's Rights Conventions prior to 1870 and the records of various female charitable organizations.

1. Keith E. Melder, "The Beginnings of the Women's Rights Movement in the United States: 1800-1840" (Diss. Yale, 1963).

Elisabeth A. Dexter, Colonial Women of Affairs: Women in Business and Professions in America before 1776 (Boston, 1931).

Career Women of America: 1776-1840 (Francestown, N.H., 1950).

2. Herbert Moller, "Sex Composition and Corresponding Culture Patterns of Colonial America," William and Mary Quarterly, Ser. 3, II (April, 1945), 113-153.

3. The summary of the status of colonial women is based on the following sources: Mary Benson, Women in 18th Century America: A Study of Opinion and Social Usage (New York, 1935); Arthur Calhoun, $A$ Social History of the American Family, 3 vols. (Cleveland, 1918); Dexter, Colonial Women; Dexter, Career Women; Edmund S. Morgan, Virginians at Home: Family Life in the 18th Century (Williamsburg, 1952); Julia G. Spruill, Women's Life and Work in the Southern Colonies (Chapel Hill, 1938).

4. E. M. Boatwright, "The political and legal status of women in Georgia: 1783-1860," Georgia Historical Quarterly, XXV (April, 1941).

Richard B. Morris, Studies in the History of American Law (New York, 1930), Chap. 3.

A summary of travelers' comments on American women may be found in: Jane Mesick, The English Traveler in America: 1785-1835 (New York, 1922), 83-99.

5. For facts on colonial medicine the following sources were consulted: Wyndham $B$. Blanton, Medicine in Virginia, 3 vols. (Richmond, 1930); N. S. Davis, M.D., History of Medical 
Education and Institutions in the United States . . . (Chicago, 1851); Dexter, Career Women; K. C. Hurd-Mead, M.D., A History of Women in Medicine: from the earliest Times to the Beginning of the 19th Century (Haddam, Conn., 1938); Geo. W. Norris, The Early History of Medicine in Philadelphia (Philadelphia, 1886); Joseph M. Toner, Contributions to the Annals of Medical Progress in the United States before and during the War of Independence (Washington, D.C., 1874).

The citation regarding Mrs. Allyn is from Hurd-Mead, Women in Medicine, 487. 1929).

6. Fielding H. Garrison, M.D., An Introduction to the History of Medicine (Philadelphia,

For licensing legislation: Davis, 88-103.

7. George Daniels, "The Professionalization of American Science: the emergent period, 1820-1860," paper delivered at the joint session of the History of Science Society and the Society of the History of Technology, San Francisco, December 28, 1965.

8. Hurd-Mead, Women in Medicine, 391.

9. Ibid., 486.

10. Betsy E. Corner, William Shippen Jr.: Pioneer in American Medical Education (Philadelphia, 1951), 103.

11. Ibid.

12. Benjamin Lee Gordon, Medieval and Renaissance Medicine (New York, 1959), 689-691.

Blanton, Medicine, II, 23-24; Hurd-Mead, Women in Medicine, 487-88; Annie Nathan Meyer, Woman's Work in America (New York, 1891).

Harriot K. Hunt, M.D., Glances and Glimpses or Fifty Years Social including Twenty Years Professional Life (Boston, 1856), 127-140.

Eleanor Flexner, Century of Struggle: The Woman's Rights Movement in the United States (Cambridge, Mass., 1959), 115-119.

13. Sophie H. Drinker, "Women Attorneys of Colonial Times," Maryland Historical Society Bulletin, LVI, No. 4 (Dec., 1961).

14. Dexter, Colonial Women, 34-35, 162-165.

15. Harriet W. Marr, The Old New England Academies (New York, 1959), Chap. 8; Thomas Woody, A History of Women's Education in the United States, 2 vols. (New York, 1929) H, 100-109, 458-460, 492-493.

16. Matthew Carey, Essays on Political Economy .... (Philadelphia, 1822), 459.

17. The statements on women industrial workers are based on the following sources: Edith Abbot, Women in Industry (New York, 1910), 66-80; Edith Abbot, "Harriet Martineau and the Employment of Women in 1836," Journal of Political Economy, XIV (Dec., 1906), 614-626; Matthew Carey, Miscellaneous Essays (Philadelphia, 1830), 153-203; Helen L. Sumner, History of Women in Industry in the United States, in Report on Condition of Woman and Child Wage-Earners in the United States, 19 vols. (Washington, D.C., 1910), IX.

Also: Elizabeth F. Baker, Technology and Woman's Work (New York, 1964), Chaps. 1-5.

18. Emily Putnam, The Lady: Studies of certain significant Phases of her History (New York, 1910), 319-320.

Barbara Welter, "The Cult of True Womanhood: 1820-1860," American Quarterly, XVIII, No. 2, Part 1 (Summer, 1966), 151-174.

19. Veblen generalized from his observations of the society of the Gilded Age and fell into the usual error of simply ignoring the lower class women, whom he dismissed as "drudges . . . fairly content with their lot," but his analysis of women's role in "conspicuous consumption" and of the function of women's fashions is unsurpassed.

For references see: Thorstein Veblen, The Theory of the Leisure Class (New York, 1962, first printing, 1899), 70-71, 231-232.

Thorstein Veblen, "The Economic Theory of Woman's Dress," Essays in Our Changing Order (New York, 1934), 65-77.

20. Like most groups fighting status oppression women formulated a compensatory ideology of female superiority. Norton Mezvinsky has postulated that this was clearly expressed only in 1874; in fact this formulation appeared in the earliest speeches of Elizabeth Cady Stanton and in the speeches and resolutions of the Seneca Falls Conventions and other pre-Civil War woman's rights conventions. Rather than a main motivating force, the idea was a tactical formulation, designed to take advantage of the popularly held male belief in woman's "moral" superiority and to convince reformers that they needed the votes of women. Those middle class feminists who believed in woman's "moral" superiority exploited the concept in order to win their major goal-female equality.

For references see: Norton Mezvinsky, "An Idea of Female Superiority," Midcontinent American Studies Journal, II, No. 1 (Spring, 1961), 17-26.

E. D. Stanton, S. B. Anthony and M. J. Gage, eds., A History of Woman Suffrage, 6 vols. (New York, 1881-1922), I, 72, 479, 522, 529 and passim.

Alan P. Grimes, The Puritan Ethic and Woman Suffrage (New York, 1967), Chaps. 2 and 3.

21. Stanton et al, History of Woman Suffrage, I, 70.

22. Mary R. Beard, Woman as Force in History: A Study of Traditions and Realities (New York, 1946). 


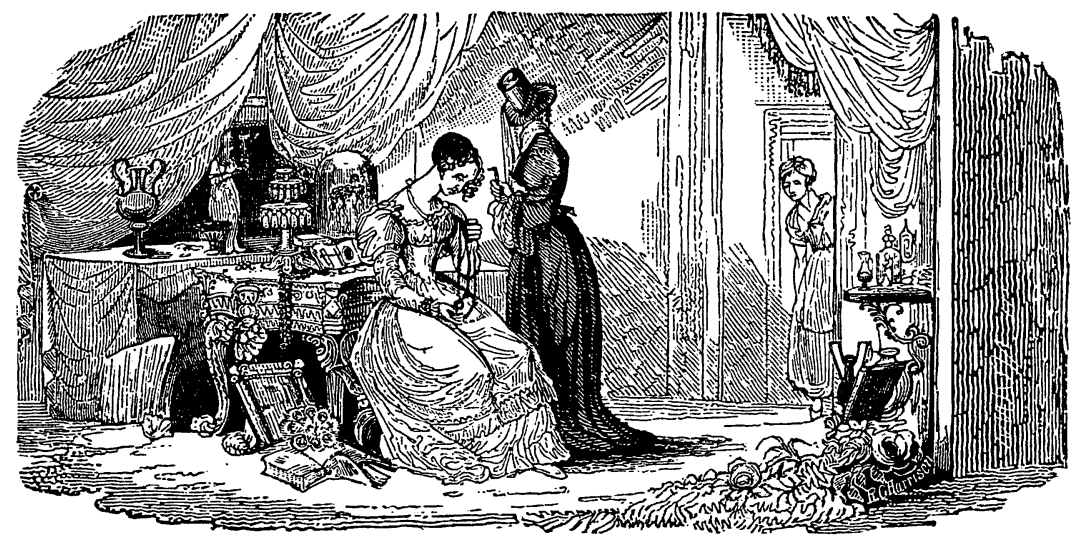

From Godey's Lady's Book, Volume II (January, 1831), page 9. See pp. 5-15. 